\title{
Citing Patterns of Indian Space Technologists ${ }^{*}$
}

\section{S. Sridhar}

Abstract: This paper probes into the publishing and citing patterns of engineers and technologists of ISRO Satellite Centre, Bangalore as part of a lager information-behaviour study; presents and analyses publishing productivity of Indian space technologists for over a decade, examines various channels/sources in which they preferred publishing and the channels cited by them. Apart from contrasting the publishing in and citing from Indian with foreign sources, frequency distribution of number of papers published and number of references cited including self citations for all the publications as well as a separate distribution for Journals as sources of publication and citation to journal articles are presented and discussed. The paper also examines availability of the channels/sources used by authors in the primary library and tries to relate 'use' in library to publishing and citing. The most popular journals as sources used by Indian space technologists are identified. The source papers and citations of the most productive authors among the group are checked in $\mathrm{SCl}$ and results reported. Paper concludes that unlike scientists, engineers and technologists, by their vary nature of work, are not much pressed by 'publish or perish' syndrome as only one fourth have ever published papers with an average of little over 2 papers per author. Even citations are not rich as $25 \%$ of papers had no citations. However, they had higher self citations than scientists in general and the channels used for citing were quite different from those used for publishing.

Keywords: Indian space technologists, citation pattern, publishing pattern, publishing productivity, self citations

\section{INTRODUCTION}

The principle of "publish or perish" is, perhaps, more applicable to academics and scientists, particularly pure scientists and social scientists, than to engineers and technologists. The practice of assessing the productivity and performance of applied scientists, engineers and technologists based on the number of papers published in reputed journals could be disastrous, although the same practice is extensively followed in the pure science and social science areas. However, engineers and technologists do interact with formal communication channels by publishing papers in journals and presenting papers in conferences apart from using many types of formal documents. This is a cyclical process of production, transference and consumption of information but there is a degree of difference among these activities. One of the methods of knowing what information a research worker uses seriously is to study citation in 
Citing patterns of Indian space technologists

his articles or papers. This study tries to probe the publishing and citing features or patterns of scientists and engineers of ISRO Satellite Centre (ISAC), Bangalore.

\section{METHODOLOGY, SAMPLE AND LIMITATIONS}

A statistical presentation and analysis of "productivity" in terms of the number of papers published by scientists and engineers; sources where published and sources from which cited including the ratio of foreign and Indian sources; frequency distribution of publishing in and citing from journals and conference proceedings; frequency distribution of the number of references cited and number of self-citations; comparison of citing and publishing in different journals and also with use in the case of most frequently published as well as cited journals, are made. Out of 224 total available references (in which at least one of the authors is from ISAC), 148 papers have been published between 1972 and 1982 and the same years are covered in this study. This sample is estimated to represent more than 25 per cent of the total papers published during the period covered. As will be shown in one of the tables later, most of these papers are journal articles and conference papers. Very few of them are preprints, lecture notes and brief communications to journals. Thus the word "publishing" in this study includes presenting a paper in conference, preprints and lecture notes. Thus, technical reports, books, monographs, theses or dissertations and private communications are excluded from the study. However, while analysing citations all such forms are considered. As mentioned earlier the concept of productivity based on the number of papers published is not only debatable but also of less relevance in space research. Further, the sample references or papers under study are not systematically drawn but consist of all those references and papers made available by authors at request.

Lastly, although citation analysis has been extensively used as "an adjunct of the peer review process" in assessing the scientific productivity, and many other related purposes, there is a considerable amount of for and against arguments about the validity of this tool. ${ }^{1}$

\section{PRODUCTIVITY}

A chronological breakup of the number of papers published between 1972 and 1982 is presented in Table I. The productivity is more or less uniform except for the year 1978 and to some extent 1975 and 1976. There is a weak indication that slightly more number of papers are published in the year following the year of completion of major projects of the organisation.

\section{SOURCES IN WHICH PUBLISHED AND FROM WHERE CITED}

Table II depicts various sources in which 148 papers are published and sources from which 713 citations are made by space technologists. The majority of papers (i.e. 57\%) are published in 31 journals. Conference papers and journal articles put together constitute more 
Citing patterns of Indian space technologists

than $90 \%$ of sample papers. Even the majority of citations (i.e. $60 \%$ ) are from 90 journals. The next highest citations are from books and monographs (14\%), reports (10\%) and conference papers (9\%). These sources put together constitute nearly $95 \%$ of citations. ${ }^{2}$

Table I

Productivity of Papers

\begin{tabular}{cccc} 
Year & $\begin{array}{c}\text { No. of } \\
\text { Papers }\end{array}$ & Percentage & $\begin{array}{c}\text { Cumulative } \\
\text { Percentage }\end{array}$ \\
\hline 1972 & 8 & 5.4 & 5.4 \\
1973 & 11 & 7.4 & 12.8 \\
1974 & 9 & 6.1 & 18.9 \\
1975 & 16 & 10.8 & 29.7 \\
1976 & 16 & 10.8 & 40.5 \\
1977 & 7 & 4.7 & 45.2 \\
1978 & 33 & 22.3 & 07.5 \\
1979 & 10 & 6.8 & 74.3 \\
1980 & 12 & 8.1 & 82.4 \\
1981 & 13 & 8.8 & 91.2 \\
1982 & 13 & 8.8 & 100.0 \\
\hline Total & 148 & 100.0 & 100.0 \\
\hline
\end{tabular}

Table II

Sources in which published and from where cited (no. of journals in brackets)

\begin{tabular}{|c|c|c|c|c|}
\hline \multirow[t]{2}{*}{ Sources } & \multicolumn{2}{|c|}{ Published } & \multicolumn{2}{|c|}{ Cited } \\
\hline & No. & $1 \%$ & No. & $\%$ \\
\hline Joumal articles & $\begin{array}{r}85 \\
(31)\end{array}$ & 57.4 & $\begin{array}{r}432 \\
(90)\end{array}$ & 60.6 \\
\hline Books and monographs & NA & NA & 103 & 14.4 \\
\hline Reports* & NA & NA & 72 & 10.1 \\
\hline Conference papers & 49 & 33.1 & 69 & 9.7 \\
\hline Theses and dissertations & NA & NA & 16 & 2.2 \\
\hline Preprints & 5 & 3.4 & 14 & 2.0 \\
\hline Lecture notes & 9 & 6.1 & 2 & 0.3 \\
\hline Standards & NA & NA & 1 & 0.1 \\
\hline Product catalogues & NA & NA & 1 & 0.1 \\
\hline Private communication & NA & NA & 3 & 0.4 \\
\hline Total & 148 & 100.0 & 713 & 99.9 \\
\hline
\end{tabular}

Key: NA-Not available; *-About 200 to 400 intemal reports are broughtout cvery year. 
By comparing the publishing and citing sources in the table we can see that the percentage of conference papers brought out is more than that cited, and the percentage of journal articles published and cited are almost the same. Thus, it may be concluded that space technologists have a flair for oral conference presentation rather than archival publication such as a journal article (assuming that all other factors remain the same). Though the exact data about the publication of books and reports is not presented, it is observed that the percentage of reports brought out is more than that cited and the percentage of books cited is much more than the percentage of books published. A further detailed analysis of publishing in and citing from journals is presented in a later section.

Table III presents a clear and glaring difference between Indian and foreign sources. If $46 \%$ of papers are published in Indian journals only $3 \%$ of journal articles cited are of Indian origin. Compared to journal articles, a greater number (67\%) of conference papers are presented at foreign and international conferences. By and large both published and cited sources are slanted towards foreign sources, a trend that is more significant in the citations to reports and journal articles. Hence it can be safely said that, as one might expect, Indian journals serve more as publishing outlets to space technologists than sources for citing. In other words, as a corollary we can say that journals which are used for publishing are less cited (excepting self-cited journal articles).

Table III

Indian sources versus foreign Sources (no. of journals in brackets)

\begin{tabular}{|c|c|c|c|c|c|c|c|c|}
\hline \multirow[t]{3}{*}{ Sources } & \multicolumn{4}{|c|}{ Published } & \multicolumn{4}{|c|}{ Cited } \\
\hline & \multicolumn{2}{|c|}{ Indian } & \multicolumn{2}{|c|}{ Foreign: } & \multicolumn{2}{|c|}{ Indian } & \multicolumn{2}{|c|}{ Foreign } \\
\hline & No. & $1 \%$ & No. & $\%$ & No. & $\%$ & No. & $\%$ \\
\hline Joumal articles & $\begin{array}{c}39 \\
(10)\end{array}$ & $45.9^{*}$ & $\begin{array}{c}46 \\
(21)\end{array}$ & $54.1^{*}$ & $\begin{array}{c}14 \\
\text { (7) }\end{array}$ & 3.2 & $\begin{array}{l}418 \\
(83)\end{array}$ & 96.8 \\
\hline Conference papers & 16 & 32.7 & 33 & 67.3 & NAt & & $\mathrm{NA}^{+}$ & \\
\hline Reports & $\mathrm{NA}_{+}^{+}$ & & $\mathrm{NA}_{+}^{+}$ & & 15 & 20.8 & 57 & 79.2 \\
\hline
\end{tabular}

Note: * Another recent survey revealed that academics and scientists in India publish, respectively, 57.7 per cent and 41.1 per cent of their articles in Indian journals. See V. Bhavani (1982). "Publication Activities of Indian Scientists a Survey", Library Science Slan. Doc. 19(1), 54-68.

† The majority of the conference papers are presented either in foreign conferences or in international conferences.

$\ddagger$ Obviously all the reports published are Indian. 


\section{PUBLISHING AND CITING PATTERNS}

To get an overall picture of publishing pattern, all the 800 technical staff (other than medical, transport and library staff and helpers) were requested to provide the number of papers published by them. The frequency distribution of 707 papers published by the 489 persons who responded is once again presented in Table IV. Out of the 800 persons contacted about 400 were scientists and engineers and the remaining were lower level technical staff.

At the macro level, out of about 400 scientists and engineers in the centre only 107 (i.e., a little over 25\%) have ever published a paper. This percentage may marginally increase when the entire population of papers is studied. As mentioned earlier, 224 references to papers of 107 ISAC authors were initially available for this study. This amounts to an average of 2.09 papers per author. As far as a citing pattern is concerned, the average number of citations per paper is 7.35 (i.e., $713 \div 97$ ) and the percentage of self-citation is 16.4 (i.e., $\{117 \div 7 \mid 3\} \times 100$ ).

Table IV

Frequency distribution of the number of papers published by ISAC technical personne/*

\begin{tabular}{|c|c|c|c|c|c|c|}
\hline \multirow{2}{*}{$\begin{array}{l}\text { No. of } \\
\text { Papers }\end{array}$} & \multirow{2}{*}{$\begin{array}{c}\text { No. of } \\
\text { Persons }\end{array}$} & \multirow{2}{*}{$\begin{array}{c}\text { Percentage } \\
\text { of } \\
\text { Persons }\end{array}$} & \multirow{2}{*}{$\begin{array}{c}\text { Citmulative } \\
\% \text { of } \\
\text { Persons }\end{array}$} & \multicolumn{3}{|c|}{ Total Papers } \\
\hline & & & & No. & $1 \%$ & Cumulative "ii \\
\hline 0 & $382 t$ & 78.12 & 78.12 & 0 & 0.00 & 0.00 \\
\hline 1 & 35 & 7.16 & 85.28 & 35 & 4.95 & 4.95 \\
\hline 2 & 14 & 2.86 & 88.14 & 28 & $3.90^{\circ}$ & 8.91 \\
\hline 3 & 9 & 1.84 & 89.98 & 27 & 3.82 & 12.73 \\
\hline 4 & 9 & 1.84 & 91.82 & 36 & 5.09 & 17.82 \\
\hline 5 & 4 & 0.82 & 92.64 & 20 & 2.83 & 20.65 \\
\hline 6 & 6 & 1.23 & 93.87 & 36 & 5.09 & 25.74 \\
\hline 7 & 3 & 0.61 & 94.48 & 21 & 2.97 & 28.71 \\
\hline 8 & 4 & 0.82 & 95.30 & 32 & 4.53 & 33.24 \\
\hline 9 & 0 & 0.00 & 95.30 & 0 & 0.00 & 33.24 \\
\hline 10 & 3 & 0.61 & 95.91 & 30 & 4.24 & 37.48 \\
\hline 11 & 1 & 0.20 & 96.11 & 11 & 1.56 & 39.04 \\
\hline 12 & 2 & 0.41 & 96.52 & 24 & 3.39 & 42.43 \\
\hline 13 & 1 & 0.20 & 96.72 & 13 & 1.84 & 44.27 \\
\hline 14 & 1 & 0.20 & 96.92 & 14 & 1.98 & 46.25 \\
\hline 15 & 6 & 1.23 & 98.15 & 90 & 12.73 & $\$ 8.98$ \\
\hline 16 & 1 & 0.20 & 98.35 & 16 & 2.26 & 61.24 \\
\hline 18 & 1 & 0.20 & 98.55 & 18 & 2.55 & 63.79 \\
\hline 20 & 1 & 0.20 & 98.75 & 20 & 2.83 & 60.02 \\
\hline 26 & 1 & 0.20 & 98.95 & 26 & 3.68 & 70.30 \\
\hline 30 & 1 & 0.20 & 99.15 & 30 & 4.24 & 74.54 \\
\hline 40 & 2 & $0.4 !$ & 99.15 & 80 & 11.32 & 85.86 \\
\hline 50 & 2 & 0.41 & 99.97 & 100 & 14.14 & .100 .00 \\
\hline Total & 489 & 99.97 & 99.97 & 707 & 100.00 & 100.00 \\
\hline Note: * & $\begin{array}{l}\text { This table } \\
\text { based on } \\
\text { Almost a }\end{array}$ & $\begin{array}{l}\text { based on c } \\
\text { al reference } \\
\text { these per } \\
\text { at lower l }\end{array}$ & $\begin{array}{l}\text { lains of the } \\
\text { es and paper } \\
\text { rsons ate ot } \\
\text { evels). }\end{array}$ & in & $\begin{array}{l}\text { as subs } \\
\text { e librar } \\
\text { ists an }\end{array}$ & $\begin{array}{l}\text { quent tables are } \\
\text { engineers (i.e.. }\end{array}$ \\
\hline
\end{tabular}

Table $V$ presents frequency distribution of number of references cited. Nearly $25 \%$ of the papers studied have no references cited. ${ }^{3}$ It is seen from the table that journal articles carry more references (with a maximum of 51 and an average of 8.9 references per paper) ${ }^{4}$ than 
Citing patterns of Indian space technologists

conference papers which mostly (except three papers) have less than five references with an average of 4.2 references per paper. In the frequency distribution one can see that 24 journal articles (i.e., one-third of total journal articles) with 10 or more references cite approximately 484 references (i.e., three-quarters of total references). Similarly, one-fifth of the conference papers cite almost three-quarters of total references.

It may be noted here that most of the conference papers and proceedings cited are from AIAA, IEEE, COSPAR and other foreign and international seminars on space technology. More than $90 \%$ of the foreign reports cited are either NASA or ESA reports. Preprints are cited by authors of astronomy and astrophysics articles only. This confirms the view that preprints distribution activity is very high in astronomy and astrophysics area.

Table $V$

Frequency distribution of number of references cited

\begin{tabular}{|c|c|c|c|c|c|c|c|c|}
\hline $\begin{array}{c}\text { No. of } \\
\text { References } \\
\text { Cited }\end{array}$ & $\begin{array}{l}\text { No. of } \\
\text { Journal } \\
\text { Articles }\end{array}$ & $\begin{array}{c}\text { rotal } \\
\text { References } \\
\text { Cited }\end{array}$ & $\begin{array}{c}\text { No. of } \\
\text { Conference } \\
\text { Papers }\end{array}$ & $\begin{array}{c}\text { Total } \\
\text { References } \\
\text { Ciled }\end{array}$ & $\begin{array}{c}\text { Other } \\
\text { Documents }\end{array}$ & $\begin{array}{c}\text { Total } \\
\text { References } \\
\text { Cired }\end{array}$ & $\begin{array}{c}\text { Tolal } \\
\text { No. of } \\
\text { Documents }\end{array}$ & $\begin{array}{c}\text { Total } \\
\text { References } \\
\text { Cited from } \\
\text { all Types of } \\
\text { Documents }\end{array}$ \\
\hline 0 & 11 & 0 & 6 & 0 & 7 & 0 & 24 & 0 \\
\hline 1 & 7 & 7 & 1 & 1 & 0 & 0 & 8 & 8 \\
\hline 2 & 5 & 10 & 0 & 0 & 0 & 0 & 5 & 10 \\
\hline 3 & 4 & 12 & 3 & 9 & 0 & 0 & 7 & 21 \\
\hline 4 & 6 & 24 & 2 & 8 & 0 & 0 & 8 & 32 \\
\hline 5 & 2 & 10 & 0 & 0 & 0 & 0 & 2 & 10 \\
\hline 6 & 3 & 18 & 0 & 0 & 1 & 6 & 4 & 24 \\
\hline 7 & 6 & 42 & 0 & 0 & 0 & 0 & 6 & 42 \\
\hline 8 & 2 & 16 & 0 & 0 & 0 & 0 & 2 & 16 \\
\hline 9 & 2 & 18 & 1 & 9 & 0 & 0 & 3 & 27 \\
\hline 10 & 3 & 20 & 0 & 0 & 0 & 0 & 3 & 30 \\
\hline $11-15$ & 11 & $143^{*}$ & 1 & 13 & 1 & 13 & 13 & 169 \\
\hline $16-20$ & 3 & $54^{*}$ & 0 & 0 & 0 & 0 & 3 & 54 \\
\hline \multirow{2}{*}{$\begin{array}{l}21-25 \\
26 \text { and } \\
\text { above }\end{array}$} & 1 & $23^{*}$ & 1 & 23 & 0 & 0 & 2 & 46 \\
\hline & 6 & $234^{*}$ & 0 & 0 & 1 & 39 & 7 & 273 \\
\hline Total & 72 & 641 & 15 & 63 & 10 & 58 & 97 & 762 \\
\hline
\end{tabular}

Nole: * Worked out based on mcan of the range.

The extent of self-citation by space technologists is presented in the frequency distribution Table VI. It may be noticed that as many as $35 \%$ of papers have one or more self-citations. The average self-citation among these papers is 3.44 . However, about $15 \%$ of total papers (or $44 \%$ of papers having self-citations) have only one self-citation.

Although detailed analysis is not carried out, the following personal informal observations are interesting. Firstly, all the 15 Indian reports cited (out of total 72 citations of reports) are internal reports and most of them are self-citations. Secondly, most of the theses cited are self-citations. Lastly, apart from self-citations, there are a considerable number of citations of papers by other ISAC authors. 
Table VI

Frequency distribution of self-citation

\begin{tabular}{|c|c|c|c|c|c|c|c|c|}
\hline \multirow{3}{*}{$\begin{array}{c}\text { No. of } \\
\text { Self- } \\
\text { citations }\end{array}$} & \multirow{2}{*}{\multicolumn{2}{|c|}{$\begin{array}{l}\text { Journal } \\
\text { Articles }\end{array}$}} & \multirow{2}{*}{\multicolumn{2}{|c|}{$\begin{array}{c}\text { Conference } \\
\text { Papers }\end{array}$}} & \multicolumn{2}{|c|}{ Others } & \multicolumn{2}{|c|}{ Total } \\
\hline & & & & & \multirow{2}{*}{$\begin{array}{l}\text { No. of } \\
\text { Docu- } \\
\text { ments }\end{array}$} & \multirow{2}{*}{$\begin{array}{l}\text { Total } \\
\text { Self- } \\
\text { Citalions }\end{array}$} & \multirow{2}{*}{$\begin{array}{c}\text { No. of } \\
\text { Papers } \\
\text { or Doct- } \\
\text { ments }\end{array}$} & \multirow{2}{*}{$\begin{array}{l}\text { Total } \\
\text { Self- } \\
\text { Citations }\end{array}$} \\
\hline & $\begin{array}{l}\text { No. of } \\
\text { Articles }\end{array}$ & $\begin{array}{c}\text { Total } \\
\text { Self- } \\
\text { Citations }\end{array}$ & $\begin{array}{l}\text { No. of } \\
\text { Papers }\end{array}$ & $\begin{array}{c}\text { Total } \\
\text { Self- } \\
\text { Citations }\end{array}$ & & & & \\
\hline 0 & 42 & 0 & 12 & 0 & 9 & 0 & 63 & 0 \\
\hline 1 & 12 & 12 & 3 & 3 & 0 & 0 & 15 & 15 \\
\hline 2 & 7 & 14 & 0 & 0 & 0 & 0 & 7 & 14 \\
\hline 3 & 6 & 18 & 0 & 0 & 0 & 0 & 0 & 18 \\
\hline 4 & 0 & 0 & 0 & 0 & 0 & 0 & 0. & 0 \\
\hline 5 & 2 & 10 & 0 & 0 & 0 & 0 & 2 & 10 \\
\hline 6 & 0 & 0 & 0 & 0 & 0 & 0 & 0 & 0 \\
\hline 7 & 2 & 14 & 0 & 0 & 0 & 0 & 2 & 14 \\
\hline 8 & 0 & 0 & 0 & 0 & 0 & 0 & 0 & 0 \\
\hline 9 & 1 & 9 & 0 & 0 & 0 & 0 & 1 & 9 \\
\hline 37 & 0 & 0 & 0 & 0 & 1 & 37 & 1 & 37 \\
\hline Total & 72 & 77 & 15 & 3 & 10 & 37 & 97 & 117 \\
\hline
\end{tabular}

\section{PUBLISHING IN JOURNALS AND CITING FROM JOURNALS}

A comparison of the frequency distribution of the number of papers published in journals with the number of papers cited from journals is shown in Table VII. Out of 31 journals used for publishing articles and 90 journals from which citations are made 23 are common. In other words, nearly $75 \%$ of journals used for publishing papers were also used for citing references. As can be seen from the table the number of papers published in journals varies from one to seven. However, there is one exceptional journal which has accommodated 16 articles or papers of Indian space technologists. On the other hand, the number of papers cited from a journal ranges from one to 59 . Eight journals (or a little over 25\% of the journals) published 53 papers (or more than $62 \%$ of the papers) of Indian space technologists. Similarly 10 journals (accounting for a little over 21\% of journals) were in all cited 259 times (or nearly $60 \%$ of references are from these 10 journals). These most frequently used journals for publishing as well as citing are analysed further in the next section. 
Table VII

Frequency distribution of number of papers published in and cited from journals

\begin{tabular}{|c|c|c|c|c|c|c|c|c|}
\hline \multirow{3}{*}{$\begin{array}{l}\text { No. of } \\
\text { Papers }\end{array}$} & \multicolumn{4}{|c|}{ Published } & \multicolumn{4}{|c|}{ Cited } \\
\hline & \multicolumn{2}{|c|}{ Journals } & \multicolumn{2}{|c|}{ Total Papers } & \multicolumn{2}{|c|}{ Journals } & \multicolumn{2}{|c|}{ Total Papers } \\
\hline & No. & $\%$ & No. & $\%$ & No. & $\%$ & No. & Dit \\
\hline 1 & 14 & 45.2 & 14 & 16.5 & 35 & 38.9 & 35 & 8.1 \\
\hline 2 & 9 & 29.0 & 18 & 20.2 & 22 & 24.4 & 44 & 10.2 \\
\hline 3 & 2 & 6.5 & 6 & 7.1 & 7 & 7.8 & 21 & 4.9 \\
\hline 4 & 0 & 0.0 & 0 & 0.0 & 10 & 11.1 & 40 & 9.3 \\
\hline 5 & 1 & 3.2 & 5 & 5.9 & 3 & - 3.3 & 15 & 3.5 \\
\hline 6 & 2 & 6.5 & 12 & 14.1 & 3 & 3.1 & 18 & 4.2 \\
\hline 7 & 2 & 6.5 & 14 & 16.5 & 1 & 1.1 & 7 & 1.0 \\
\hline 8 & 0 & 0.0 & 0 & 0.0 & 1 & 1.1 & 8 & 1.9 \\
\hline 11 & 0 & 0.0 & 0 & 0.0 & 1 & 1.1 & 11 & 2.5 \\
\hline 14 & 0 & 0.0 & 0 & 0.0 & 1 & 1.1 & 14 & 3.2 \\
\hline 16 & 1 & 3.2 & 16 & 18.8 & 1 & 1.1 & 16 & 3.7 \\
\hline 25 & 0 & 0.0 & 0 & 0.0 & 2 & 2.2 & 50 & 11.0 \\
\hline 44 & 0 & 0.0 & 0 & 0.0 & 1 & 1.1 & 44 & 10.2 \\
\hline 50 & 0 & 0.0 & 0 & 0.0 & 1 & 1.1 & 50 & 11.0 \\
\hline 59 & 0 & 0.0 & 0 & 0.0 & 1 & 1.1 & 59 & 13.7 \\
\hline Total & 31 & 100.1 & 85 & 101.1 & 90 & 99.6 & 432 & 100.2 \\
\hline
\end{tabular}

Table VIII

Share of local and foreign journals in publishing and citing (percentages in brackets)

\begin{tabular}{lcccccc}
\hline $\begin{array}{l}\text { Local or } \\
\text { Foreign }\end{array}$ & \multicolumn{2}{c}{ Published } & & \multicolumn{2}{c}{ Cited } & $\begin{array}{c}\text { Total No. of } \\
\text { Jownals }\end{array}$ \\
\cline { 2 - 3 } & $\begin{array}{c}\text { No. of } \\
\text { Journals }\end{array}$ & $\begin{array}{c}\text { No. of } \\
\text { Articles }\end{array}$ & & $\begin{array}{c}\text { No. of } \\
\text { Journals }\end{array}$ & $\begin{array}{c}\text { No. of } \\
\text { Articles }\end{array}$ & \\
\hline Indian & 10 & 39 & & 7 & 14 & 11 \\
Foreign & $(32.3)$ & $(45.9)$ & & $(7.8)$ & $(3.2)$ & $(11.2)$ \\
& 21 & 46 & & 83 & 418 & 87 \\
& $(67.7)$ & $(54.1)$ & $(92.2)$ & $(96.8)$ & $(88.8)$ \\
\hline Total & 31 & 85 & 90 & 432 & $98 *$ \\
\hline
\end{tabular}

Note: * Twenty-lhree journals are common to publishing and citing.

The pattern of local and foreign journals used for publishing and citing is depicted in Table VIII. Out of 98 journals used by space technologists for publishing and for citing, 11 are of Indian origin. As revealed earlier, the contrasting picture of "high publishing and low citing" profile in Indian journals is clear from the fact that while nearly $46 \%$ of papers are published in Indian journals, hardly $4 \%$ of the references cited are from Indian journals. Only one Indian journal is 
Citing patterns of Indian space technologists

cited where no paper from an Indian space technologist is published.

Table IX shows the availability of those journals used for publishing and citing papers at the ISAC library. It may be noted incidentally, that collection of library was not developed systematically till 1978 as it was supposed to serve a small group of workers in the project. It was only after converting the project into a full-fledged centre, the library started growing. As a result many of the journals used for publishing and/or citing earlier to 1978 are not available in the library. It may be seen that about $78 \%$ of journals used for publishing and citing are available in the library. In terms of number of papers, nearly $97 \%$ of papers published and $91 \%$ of papers cited are available in the library. The intention in this study is not to judge the relevance and adequacy of the library collection but to drive home the point that most of the times the authors under study preferred to publish in a journal available in their library and also cite from those available to the library.

Table IX

Availability of published and cited journals in the library (percentage in brackets)

\begin{tabular}{|c|c|c|c|c|c|}
\hline \multirow[t]{2}{*}{ Arailability } & \multicolumn{2}{|c|}{ Published } & \multicolumn{2}{|c|}{ Cited } & \multirow{2}{*}{$\begin{array}{c}\text { Total } \\
\text { No. of } \\
\text { Jotwinals }\end{array}$} \\
\hline & $\begin{array}{c}\text { No. of } \\
\text { Journals }\end{array}$ & $\begin{array}{c}\text { No. of } \\
\text { Articles }\end{array}$ & $\begin{array}{c}\text { No. of } \\
\text { Journals }\end{array}$ & $\begin{array}{l}\text { No. of } \\
\text { Articles }\end{array}$ & \\
\hline Available & $\begin{array}{c}28 \\
(90.3)\end{array}$ & $\begin{array}{c}82 \\
(96.5)\end{array}$ & $\begin{array}{c}69 \\
(76.7)\end{array}$ & $\begin{array}{c}390 \\
(90.3)\end{array}$ & $\begin{array}{c}70 \\
(77.6)\end{array}$ \\
\hline Not available & 3 & 3 & 21 & 42 & 22 \\
\hline Total & 31 & 85 & 90 & 432 & 98 \\
\hline
\end{tabular}

\section{PUBLISHING AND CITING VERSUS USE}

The most popular journals for publishing and citing are presented in Tables $\mathrm{X}$ and $\mathrm{XI}$ respectively with publishing, citing and use data. Use of a journal in these tables is sub-divided into the number of pages of Xerox copies taken from the journal during 1982; the number of times two issues of the journal are issued out and the number of times the journal is consulted over the three months immediately after receipt in the ISAC library. The number of pages of Xerox copies taken from about 650 journals in the library for one year is about 7600 . Out of the 98 journals covered in this study (of which 87 are available in the library) 40 journals were used for taking 3215 pages of Xerox copies and use data is collected for 56 titles (i.e., 112 issues of 56 journals were monitored over three months to record 921 uses). In other words, a little over 
Citing patterns of Indian space technologists

$13 \%$ of the journals (used for publishing and citing) have been used for taking nearly $42 \%$ of total Xerox copies.

Thus at this level, there is a correlation between publishing and citing with the use of journals. It may be noted that the number of journals which arc common to publishing and citing and those used for taking Xerox copies in the study is only 15.

A close examination of Tables $X$ and $X I$ reveals that no clear correlation can be found of journals frequently used for publishing and citing with that of the use of these journals. Thus, title by title correlation fails, though at a broad level journals used for publishing and citing have registered considerably more use. The possible reason for non-correlation in this limited data of "use" is that xerox copies of a journal article are taken for many purposes, and writing a paper, citing an article xeroxed and publishing the paper in the same journal are only a few of those purposes. As it is set out in a separate use study, the quantitative use is influenced by many factors like the number of journals in a field, the number of users in a field, journal circulation policy: etc.

Again by looking at publishing and citing data in these two tables, we see that not all the journals frequently used for publishing are highly cited and vice versa (with the exception of two titles in each table). However, all highly used journals for publishing have one or more citations. Self-citations have played a great role in this direction. It is the self-citations which boosted the score of Indian journals in these tables. On the other hand all but two journals highly cited have been used for publishing one or more papers.

Table $X$ Most popular journals for publishing with scores of citation and use

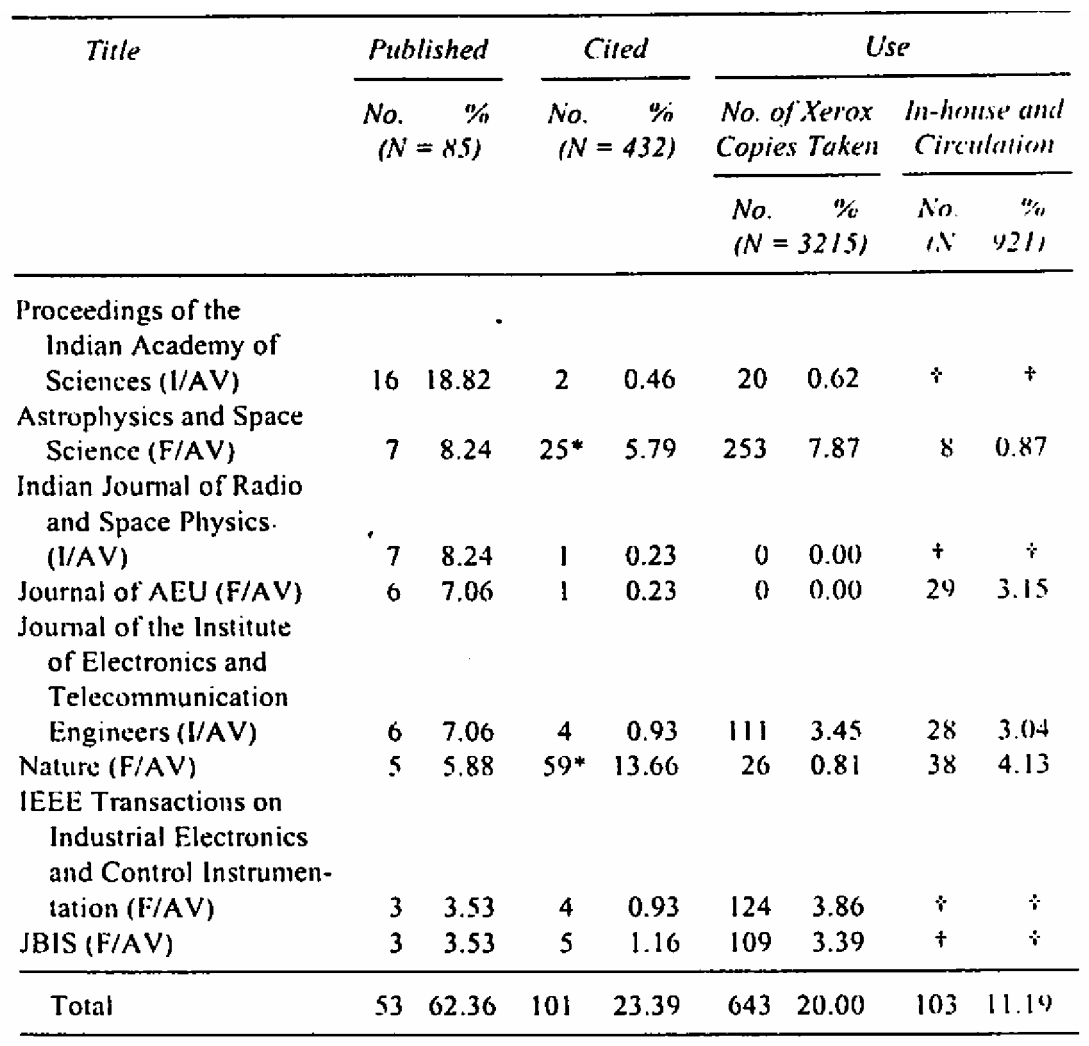


Table XI Most often cited journals with scores of publishing and use

\begin{tabular}{|c|c|c|c|c|c|c|c|c|}
\hline \multirow{4}{*}{$\begin{array}{l}\text { Title } \\
\text { Nature (F/AV) }\end{array}$} & \multicolumn{2}{|c|}{ Cired } & \multicolumn{2}{|c|}{ Published } & \multicolumn{4}{|c|}{ Use } \\
\hline & \multicolumn{2}{|c|}{$\begin{array}{l}\text { No. } \quad \%(1 ; \\
(N=432)\end{array}$} & \multirow[t]{2}{*}{$\begin{array}{l}\text { No. } \\
\qquad N=\end{array}$} & \multirow[t]{2}{*}{ (111 } & \multicolumn{2}{|c|}{$\begin{array}{l}\text { Nr. of Xrox } \\
\text { Copies Taken }\end{array}$} & \multicolumn{2}{|c|}{$\begin{array}{c}\text { In-house and } \\
\text { Civculation }\end{array}$} \\
\hline & & & & & $\begin{array}{l}\text { No. } \\
N=\end{array}$ & 3215 & $\begin{array}{l}\text { No. } \\
N=\end{array}$ & $=0211$ \\
\hline & 59 & 13.66 & $5^{*}$ & 5.88 & 26 & 0.81 & 38 & 4.13 \\
\hline Letter's (F/AV) & 50 & 1.57 & 0 & 0.00 & 0 & 0.00 & 8 & 0.87 \\
\hline $\begin{array}{l}\text { Astrophysical Joumal } \\
\text { (F/AV) } \\
\text { Astrophysics and Space }\end{array}$ & 44 & 10.19 & 1 & 1.18 & 220 & 7.03 & 16 & 1.74 \\
\hline $\begin{array}{l}\text { Science (F/AV) } \\
\text { Joumal of Geophysical }\end{array}$ & 25 & 5.79 & $7^{*}$ & 8.24 & 253 & 7.87 & 8 & 0.87 \\
\hline $\begin{array}{l}\text { Research (F/AV) } \\
\text { Journal of Spacecrafts }\end{array}$ & 25 & 5.79 & 1 & 1.18 & 3 & 0.09 & 3 & 0.33 \\
\hline $\begin{array}{l}\text { and Ruckets (F/AV) } \\
\text { Planemy and Space }\end{array}$ & 16 & 3.70 & 1 & 1.18 & 59 & 1.84 & 32 & 3.47 \\
\hline Science (F/AV) & 14 & 3.24 & 2 & 2.35 & 0 & 0.00 & 13 & 1.41 \\
\hline $\begin{array}{l}\text { Space Science Reviews } \\
\text { (F/AV) }\end{array}$ & 11 & 2.55 & 2 & 2.35 & 206 & 6.41 & 2 & 0.22 \\
\hline $\begin{array}{l}\text { Solar Physics (F/AV) } \\
\text { Joumal of Atmospheric } \\
\text { and Terrestrial Physics } \\
\text { (F/AV) }\end{array}$ & 8 & 1.85 & 1 & 1.18 & 0 & 0.00 & 2 & 0.22 \\
\hline Total & 259 & 59.96 & 20 & 23.54 & 773 & 24.05 & 122 & 13.20 \\
\hline
\end{tabular}

An interesting observation is that all the 18 journals which are highly cited and used for publishing papers are available at ISAC library. Additionally, almost all highly cited journals are foreign journals. But three of the eight journals popular for publishing papers are Indian.

Other observations made, though not statistically proved, in this study are as follows. The majority of the papers are written by scientists (i.e., those possessing science degrees). A considerable number of papers are in the astronomy and astrophysics areas and hence, obviously, journals in these areas have received more citation scores.

Although not relevant in this study, one might be curious to know how others cite Indian space technologists. For this analysis, probably the only tool available is the Science Citation Index (SCl). A search through the 1982 annual indexes of the $\mathrm{SCl}$ for source papers as well as citations to 10 highly productive ISAC authors is tabulated in Table XII. All the citations except one citation for author at serial number one are made by foreign authors or authors abroad.

As the $\mathrm{SCl}$ covers a limited number of Indian journals and there is considerable selfcitation among Indian space technologists, the result in Table XII is quite obvious. A small difficulty is also encountered in the collection of the data especially consulting the citation index 


\section{Citing patterns of Indian space technologists}

and segregating the citations of four authors having names identical with other Indian scientists and engineers in other fields. As an illustration one can see as many as 139 source articles listed under A.K. Jain and these articles are cited by 203 papers in various fields like communication, demography, nuclear physics, geology, electronics, astrophysics, medicine, chemistry, etc. It would be of great use if the SCI provides author affiliation of cited papers in the citation index also.

\section{RESULTS AND OBSERVATIONS}

Subject to the limitations noted earlier, the following results and observations can be made based on the analysis made so far.

Conference papers and journal articles constitute more than 90\% of what Indian space technologists write and publish. However, the order of sources used for citation differs and, in order of decreasing use for citation, they are journals, books, technical reports and conference papers. The percentage of journal articles cited and published are almost the same. But the percentage of conference papers cited (in spite of the fact that the majority of conference papers are presented in foreign and international conferences rather than Indian conferences, unlike journal articles) is much less than those brought out. Hence, there is an inclination for oral conference presentation (and possibly semi-formal publications such as technical reports) than archival publication on the part of Indian space technologists. Journal articles cited (3\%) from Indian journals is much less than that published (46\%). In other words, Indian journals and foreign and international conferences serve more as publishing outlets to space technologists than sources for citing.

Table XII

Source papers and citations to papers of highly productive ISAC authors by others (based on $1982 \mathrm{SCl}$ )

\begin{tabular}{ccc}
\hline Si. & $\begin{array}{c}\text { No. of Source } \\
\text { Papers }\end{array}$ & $\begin{array}{c}\text { No. of Times } \\
\text { Cited }\end{array}$ \\
\hline 1. & 2 & 5 \\
2. & 0 & 2 \\
3. & 0 & 1 \\
4. & 0 & 1 \\
5. & 0 & 0 \\
6. & 0 & 1 \\
7. & 0 & 0 \\
8. & 0 & 0 \\
9. & 0 & 0 \\
10. & 0 & 1 \\
\hline Total & 2 & 11 \\
\hline
\end{tabular}

Only a little over $25 \%$ of scientists and engineers in the Centre have ever published any 
Citing patterns of Indian space technologists

paper with an average of 2.09 papers per author, an average citation of 7.35 references per paper and $16.4 \%$ self-citations. Nearly $25 \%$ of papers do not have any citations. By and large, journal articles carry a larger number of references and are cited more frequently than conference papers. One-third of total journal articles covered in this study having 10 or more references, contributed approximately to three-quarters of total references cited.

Self-citation among Indian space technologists is quite high (i.e., 35\% of papers have one or more self-citations). The average number of self-citations per paper is 3.44. Obviously, most of the Indian reports cited are self-citations or citations of the colleagues in the same organisation. More than $90 \%$ of foreign reports cited are either NASA or ESA reports. Preprint citations appear only in the astronomy and astrophysics areas.

Nearly $75 \%$ of journals used for publishing papers were also used for citing references (including self-citations). A little over $25 \%$ of the journals published more than $62 \%$ of papers, and a little over $21 \%$ of them had 60 per cent of the total citations. As stated earlier, Indian journals claim a profile of "high publishing and low citing" as far as space technologists are concerned.

Nearly $97 \%$ of journal articles published and 91\% journal articles cited are from journals available in the library, which indicates that the library is aware of the needs of the users and that the Indian space technologists mostly publish and cite from journals available at the library.

A little over $13 \%$ of journals used for publishing and citing papers have been used by Indian space technologists for nearly $42 \%$ of total xerox copies taken in one year. This indicates a slight positive correlation of publishing and citing with use of journals. However, a clear title by title correlation of publishing and citing with use of journals does not exist.

Not all the journals highly used for publishing papers are highly cited and vice versa. However, all highly used journals for publishing papers are cited at least once, Self-citations have played a great role in this direction. All but two highly cited journals have been used for publishing at least one paper.

All highly used journals for publishing papers and highly cited journals are available in the library and all highly cited journals are of foreign origin. But three out of eight highly used journals for publishing papers are of Indian origin.

\section{CONCLUSION}

Although the "user" is regarded as the king of any information system, the most neglected aspect of research in Indian librarianship is user studies in its real sense. Looking at users in different contexts and groups, at different angles, using different methods, it is necessary to probe this important, yet scarcely known, component of the information system before making any such system potentially relevant and useful. A study of publishing and citing patterns of users helps as one way of knowing the users and their role and participation in overall (scientific 
Citing patterns of Indian space technologists

and technical) information transfer cycle. In addition, such a study is useful in collection development and evaluation.

As a feedback of this study, all those journals which are used by space technologists to publish and cite articles but are not available in the library have been presented before a panel of experts for consideration to be included in the library's subscription list.

\section{ACKNOWLEDGEMENT}

Author remains highly grateful to Shri H. A. Khan, Reader, Department of Library and Information Science, University of Mysore, Mysore for going through the draft paper and offering his valuable comments.

\section{REFERENCES:}

1. 'N. Wade (1975). "Citation analysis: a new tool for science administrations", Science 188 (4187), pp. 429-432.

2. A general average is that $80 \%$ of references cited in papers are to serial publications. In the case of Indian space technologists $60.6 \%$ of references are made to journal articles. See D. J. de Solla Price (1965). "Networks of Scientific papers", Science 149, (58 64).

3. In case of journal articles 11 out of 72 or $15.3 \%$ have no references. This is against a general average of "10 percent of the paper contain no references at all". See D.J de Solla Price, oft. Cit., pp. 56 and 58.

4. "On the average there are 15 references per paper", vide Ibid.

*International Library Review 17 (3) July 1985: 259-274.

\section{About the Author}

Dr. M. S. Sridhar is a post graduate in Mathematics and Business Management and a Doctorate in Library and Information Science. He is in the profession for last 36 years. Since 1978, he is heading the Library and Documentation Division of ISRO Satellite Centre, Bangalore. Earlier he has worked in the libraries of National Aeronautical Laboratory (Bangalore), Indian Institute of Management (Bangalore) and University of Mysore. Dr.

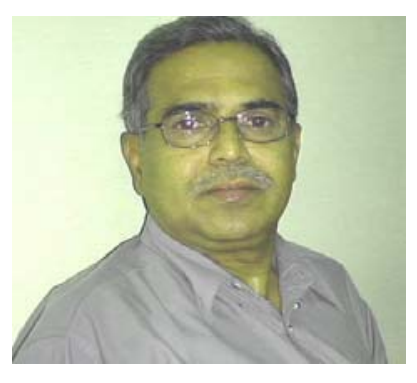
Sridhar has published 4 books, 83 research articles, 22 conferences papers, written 19 course materials for BLIS and MLIS, made over 25 seminar presentations and contributed 5 chapters to books.

E-mail: sridharmirle@yahoo.com, mirlesridhar@gmail.com, sridhar@isac.gov.in ; Phone: 91-8025084451; Fax: 91-80-25084476. 